\title{
Reducing energy poverty through carbon tax revenues in South Africa
}

\author{
Harald Winkler* \\ Energy Research Centre, University of Cape Town, Private Bag, Rondebosch 7701, South Africa
}

\begin{abstract}
How much can poverty be reduced through carbon tax revenue? This study analyses specific programmes, with carbon taxes generating revenues and equivalent spending on programmes to reduce energy poverty. The twin challenges of development and climate change could be addressed in this way in South Africa. A simple spreadsheet model was used to estimate revenue available from a carbon tax, given different tax rates and emission projections. Four programmes to reduce energy poverty were quantified: electrification, extended free basic energy, scaling-up sustainable housing, and subsidising rooftop solar for poor households. Matching carbon revenue with equivalent expenditure, the study found that applying all carbon revenue to a single programme could fund the national budget for electrification. Hundreds of thousands, and up to tens of millions, of households could receive free energy in the form of $5 \mathrm{~kg}$ of liquefied petroleum gas every month, as well as better houses that are warmer in winter and with fewer health impacts from indoor air pollution. Carbon revenues could fund at least a few hundred thousand improved homes, or subsidies for at least 100000 rooftop solar systems per year to poor households.
\end{abstract}

Institutional and other constraints would have to be addressed. Carbon revenue could fully fund all four programmes combined into an integrated strategy, in three of the four scenarios. The results suggested that full funding could be available from 2019 or from 2025, dependent on carbon tax revenue scenario. Energy poverty can be reduced by expenditure of carbon tax revenues.

Keywords: carbon prices, revenue scenarios, poverty eradication, climate change mitigation, socio-economic benefits

\section{Highlights:}

- Energy poverty can be reduced by expenditure using carbon tax revenues.

- Paper estimates revenues across a range of carbon tax rates.

- Revenues can fund large-scale programmes to reduce energy poverty: electrification, LPG, sustainable housing, rooftop solar.

- Integrated energy poverty strategy can be funded in three of four carbon revenue scenarios.

- Tax revenue could be available from 2019 to 2025.

Journal of Energy in Southern Africa 28(3):12-26

DOI: http://dx.doi.org/10.17159/2413-3051/2017/v28i3a2332

Published by the Energy Research Centre, University of Cape Town ISSN: 2413-3051 http://journals.assaf.org.za/jesa

Sponsored by the Department of Science and Technology

\footnotetext{
* Corresponding author: * Tel: +27 21 650-3230;

Email: Harald.Winkler@uct.ac.za
} 


\section{Introduction}

How much can poverty be reduced through carbon tax revenue? This study examines this question in the context of South Africa, yet it is salient for many other countries. The challenge is to address both development and climate change. More than two decades ago, the United Nations Framework Convention on Climate Change (UNFCCC) recognised that 'economic and social development and poverty eradication are the first and overriding priorities of the developing country Parties' [1]. More recently, the climate community considered goals of net zero emissions as a long-term goal by 2050 $[2,3]$, which is included by reference to a balance of sources and sinks in Article 4.1 of the Paris Agreement [4]. Zero poverty is needed as much as zero emissions, to broaden participation. The first sustainable development goal (SDG) in the post2015 development agenda is to 'end poverty in all its forms everywhere' [5]. The general argument for a development-and-climate approach remains highly relevant and needs to be implemented in specific contexts.

In South Africa, the issue can be framed in relation to an intensifying debate about introducing a carbon tax. Having long been studied [6-8], its implementation needs to take into account the top priorities identified in the National Development Plan (NDP), to reduce poverty and inequality [9]. Chapter 5 of the NDP seeks to ensure the sustainability of development, requiring 'an equitable transition to a low-carbon economy' [9], and in this context supports pricing of carbon. National Treasury's carbon tax policy design accepted that poverty-reduction mechanisms should be funded not by 'ring-fencing' or 'hard ear-marking', but with on-budget allocations to poverty programmes [10]. The current study builds on previous analysis (Section 2) in asking how much revenues generated by a carbon tax can help to alleviate poverty. The study proceeds as follows: Section 2 locates the present analysis in the broader framing of development and climate, with relevant literature review. Section 3 develops carbon tax revenue scenarios associated with different tax rates and emission projections. Four energy poverty reduction programmes are detailed in Section 4, referencing the data used and stating own assumptions made for the analysis. The next section matches carbon tax revenue and expenditure, assuming the equivalent revenue is applied to each programme singly, and all four combined into an overall strategy. The limitations of the analysis and idea for future work are outlined in Section 6 , followed by conclusions.

\section{Framing the development and climate challenge}

The specific question of how much poverty reduction can be funded by revenues from carbon-pricing mechanisms is located in a broader framework and literature. The framing of a development and climate challenge was considered in the literature over the last decade [11-22]. Over several reports from the Intergovernmental Panel on Climate Change (IPCC), climate change was increasingly assessed as a development issue [22-24]. More recent literature suggests that a new social contract may be needed for low-carbon development, requiring the rich to pay for mitigation, use less, and assist the poor; lifting the poor out of poverty; and changing the aspirations of the middle class [11]. The SDGs can be read as including elements of such a contract, with ending poverty as the first goal, as well as reducing inequality (Goal 10 ) and ensuring sustainable consumption and production patterns (Goal 12) [25].

Within this broader framing, earlier literature has examined what a development-climate approach might mean in terms of policy and policy instruments. Earlier studies made the case that instruments such as sustainable development policies and measures (SD-PAMs) would better frame action in developing countries [26-31]. The concept of SDPAMs was mooted in a dialogue under the UNFC$\mathrm{CC}$ [30] and, in the process of negotiations, became nationally appropriate mitigation action (NAMAs). Mitigation actions include carbon taxes, whether these are deemed nationally appropriate, depends on each context. The Bali Action Plan framed 'nationally appropriate mitigation actions by developing country Parties in the context of sustainable development' [32] (emphasis added) in its paragraph 1(b)(ii).

Another body of literature addresses the multiple dimensions of poverty. What does it means to reduce poverty? Poverty is not simply a lack of income, but has much broader and multiple dimensions. For example, the United Nations Development Programme (UNDP) developed a multidimensional poverty index, building on the work of Amartya Sen [33]. The UNDP adds to money metrics other measures of deprivation, including in health and education. Statistics South Africa also adopted a multi-dimensional poverty index [34]. It is, however, beyond the scope of this study to explore all the dimensions of poverty in depth, except to recognise that reducing energy poverty must address multiple dimensions. Poverty is treated as a distinct dimension from mitigation in this study, with poverty reduction programmes not limited to those that also reduce emissions. Some of the literature on carbon pricing in SA would treat poverty more generally as a contextual issue [3539]. Other studies focus on the economic implications of a carbon tax conceptually [40], while Alton et al quantify socio-economic impacts using an economy-wide model [41]. One conference paper more directly examined the potential of project- 
based carbon revenues for poverty alleviation, but argued that these revenues 'don't work for typical, small African poverty alleviation projects with low greenhouse gas emission reduction potential', and that smaller carbon registries would be a better fit [42]. In this context, the focus of this study is on using carbon revenues to reduce poverty, and on understanding how and how much that could be done. Since much of mitigation in South Africa will occur in the energy sector, reducing energy poverty may be an obvious area [43-49].

\section{Revenue from a carbon tax}

A simple spreadsheet model is used to estimate revenue available from a carbon tax, given different emission projections (hereafter referred to as carbon tax revenue scenarios). The spreadsheet is made available for download as supplementary digital information. ${ }^{1}$

\subsection{Carbon tax revenues estimated for the first year}

Details of the carbon tax have evolved and were included in draft Carbon Tax Bill in 2015 [50]. As draft legislation, it does not quantify revenues. Earlier in 2015, the total revenues from a carbon tax were estimated explicitly in a proposal by National Treasury to the Partnership for Market Readiness (PMR):

Considering that majority of GHG emissions accounted for in the GHG inventory will form the carbon tax and the marginal tax rate of $\mathrm{R} 120$ tCO2e, the amount of revenue collected from carbon tax is likely to be between R7.3 and R29.0 billion for the 2015/16 fiscal year, with the most likely amount of revenue collected being around R18 billion.[51]

The PMR proposal envisaged a maximum exemption from the ZAR 120 headline tax rate of $90 \%$, as in the earlier policy paper [10]. The draft Carbon Tax Bill [50] allowed further exemptions (see discussion on tax rate below), leading to a $95 \%$ total exemption, which would lead to lower revenues. Treasury's estimation of revenues took as its tax base emissions of $545 \mathrm{Mt} \mathrm{CO}_{2}$-eq from the National GHG inventory [52] and extrapolated that, in the fiscal year 2016/17, taxable emissions would reach $610 \mathrm{Mt} \mathrm{CO}_{2}$-eq [51].

To put the total carbon tax revenues above into perspective, a comparison with total tax revenue can be made. In 2015/16, total revenue was ZAR 1076 billion [53]. Since 2010/11, revenue has increased by $10 \%$ annually on average, so that, by linear extrapolation, total revenues would be ZAR 1182 billion in 2016/17. The share of carbon tax revenues ranges between 0.6 and $2.5 \%$ of total tax revenue, comparing the estimates in the previous paragraph with the total. The middle estimate of
ZAR 18 billion [51] is calculated to be $1.5 \%$ of total revenue of ZAR 1.18 trillion. This study follows the National Treasury's assumption that the tax is applied to all emissions in the inventory, rather than alternatives such as taxing emissions above a company-level or facility-level carbon budget, since the latter are foreseen in policy but not yet enforced. The nominal tax rate of ZAR 120 is, however, not applied, leaving only the effective rates after exemptions, as elaborated in the next section.

\subsection{Developing scenarios of carbon tax revenue}

The type of scenarios explored in this study uses a two-by-three box approach, as distinct from modelled scenarios or projections. In environmental scenario development, scenario builders consider driving forces, major characteristics, logical storylines or policy paths [54]. This can be illustrated as in Figure 1.

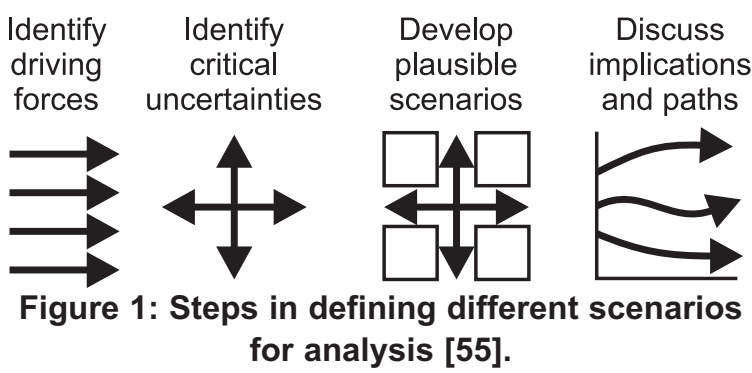

The driving forces for scenarios of how carbon tax revenue may change over time are the tax rate and the quantity of emissions taxed. Since a carbon tax is a pure price mechanism, the key uncertainty is the level of the tax rate. The tons of emissions taxed is taken to depend on the amount of mitigation that is taking place without the tax, i.e., a scenario independent of the tax. A connection could be derived, in that firms will bear costs of mitigation, if it were cheaper than paying the tax. The responsiveness of the economy to a given tax rate was not part of this study; indeed responsiveness cannot be studied empirically until the carbon tax is implemented. This study takes emissions projections from the MPA study, in which no tax was considered [56].

Scenarios of carbon tax revenues are developed by assuming tax rates can be high, medium and low, and emissions high (with existing measures) or low (with additional measures). Emissions projections and tax rate level define the dimensions, resulting in six scenarios, as illustrated in Table 1 , including the six possible scenarios for internal consistency.

The tax rates considered to develop revenue scenarios in this study draw on the assumptions by Treasury in its 2013 carbon tax policy paper [10] and the 2015 draft Carbon Tax Bill [50]. The policy paper introduced a basic tax-free allowance of 
Table 1: Possible scenarios defined by high and low emission projections and tax rates.

\begin{tabular}{lcc}
\hline & \multicolumn{2}{c}{ Emissions projection } \\
\hline Tax rate & $\begin{array}{c}\text { With existing } \\
\text { measures }\end{array}$ & $\begin{array}{c}\text { With additional } \\
\text { measures }\end{array}$ \\
\hline High & WEM-Hi & WAM-Hi \\
Medium & WEM-Med & WAM-Med \\
Low & WEM-Lo & WAM-Lo \\
\hline
\end{tabular}

Note: WEM-Hi, WEM-Med and WEM-Lo = with existing measures, with high (ZAR 48), medium (ZAR 30) and low (ZAR 6) tax rates respectively; and WAM-Hi, WAMMed and WAM-Lo = with additional measures, for the same range of tax rates.

$60 \%$, with further exemptions for process emissions, trade-exposure and off-set, each up to $10 \%$, and an intensity-related Z-factor of $\pm 5 \%$, with a maximum exemption capped at $90 \%$ [10]. The draft Carbon Tax Bill also included an additional allowance for fugitive emissions up to $10 \%$ and treatment of the Z-factor only as a reward, i.e., another 5\% allowances, with the maximum total allowances limited to 95\% [50]. Furthermore, it should be noted that the draft Carbon Tax Bill provides a detailed Schedule 2 for exemptions for various sectors and sub-sectors. It distinguishes emissions from fossil fuel combustion, industrial processes, product use and fugitive emissions with some direct and indirect emissions; although it neither explicitly refers to definitions of Scope 1, 2 and 3 emissions as in the GHG Protocol [57] nor mentions overtly the tiers used in IPCC guidelines for inventories [58]. These distinctions are not required for the current study paper, which refers simply to three tax rates, providing a range from low to high effective tax.

The effective tax rates after 60, 75 and $95 \%$ exemptions are calculated as ZAR 6, ZAR 30 and ZAR 48 per ton of $\mathrm{CO}_{2}$-equivalent, for the initial year 2016. In this study, these are referred to as high, medium and low tax rates. The tax policy is for financial years, e.g. 2016/7; in this paper these are taken as calendar years (2017); the three-month difference is not material to the analysis. The tax rates are consistent with the explanatory memorandum to the Carbon Tax Bill, stating that the effective carbon tax rate will vary between ZAR 6 and ZAR 48 per ton $\mathrm{CO}_{2}-e^{\prime}$ [50].

In the present analysis, the assumption of an increase in the tax rate of $10 \%$ per year is retained for 2016-2020 [10], and by the consumer price index (CPI) plus $2 \%$ from 2021 onwards [51]. It is further assumed that CPI remains similar to historical levels of $6 \%$ in future [59]. Under these assumptions, tax rates evolve as illustrated in Figure 2.

Emission projections are taken from the mitigation potential analysis (MPA), the projections with existing measures (WEM) and with additional measures (WAM) [56]. The WEM was taken as a reference case in the MPA, while WAM assumes mitigation actions are taken. The MPA explored scenarios in which different percentages of mitigation potential where realised. For this study, the full potential (100\% of mitigation options assessed) was considered, with $75 \%$ coverage of sectors [51]. This allowed exploration of a full range of envelope scenarios, as shown in Figure 3, with total emissions for WEM and WAM scenarios at $75 \%$ coverage, over the period 2016-2030.

The carbon tax revenue scenarios are calculated by multiplying the emissions projections and future tax rates, based on the assumptions above. Figure 4 shows the results for all six scenarios. These scenarios go to 2030, beyond the time-frame of the phases of the carbon tax as envisaged by Treasury's draft Carbon Tax Bill.

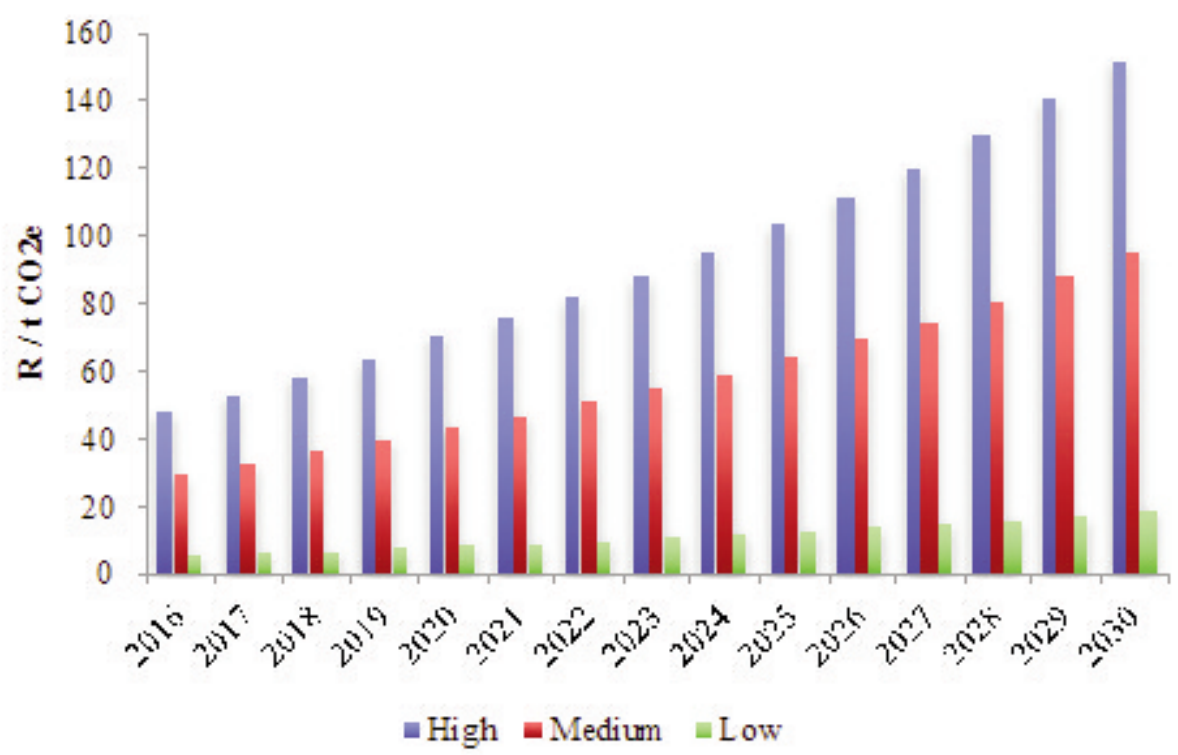

Figure 2: High medium and low tax rates, 2016-2030, where $\mathrm{CO}_{\mathrm{e}}=\mathrm{CO}_{2}$-equivalent. 


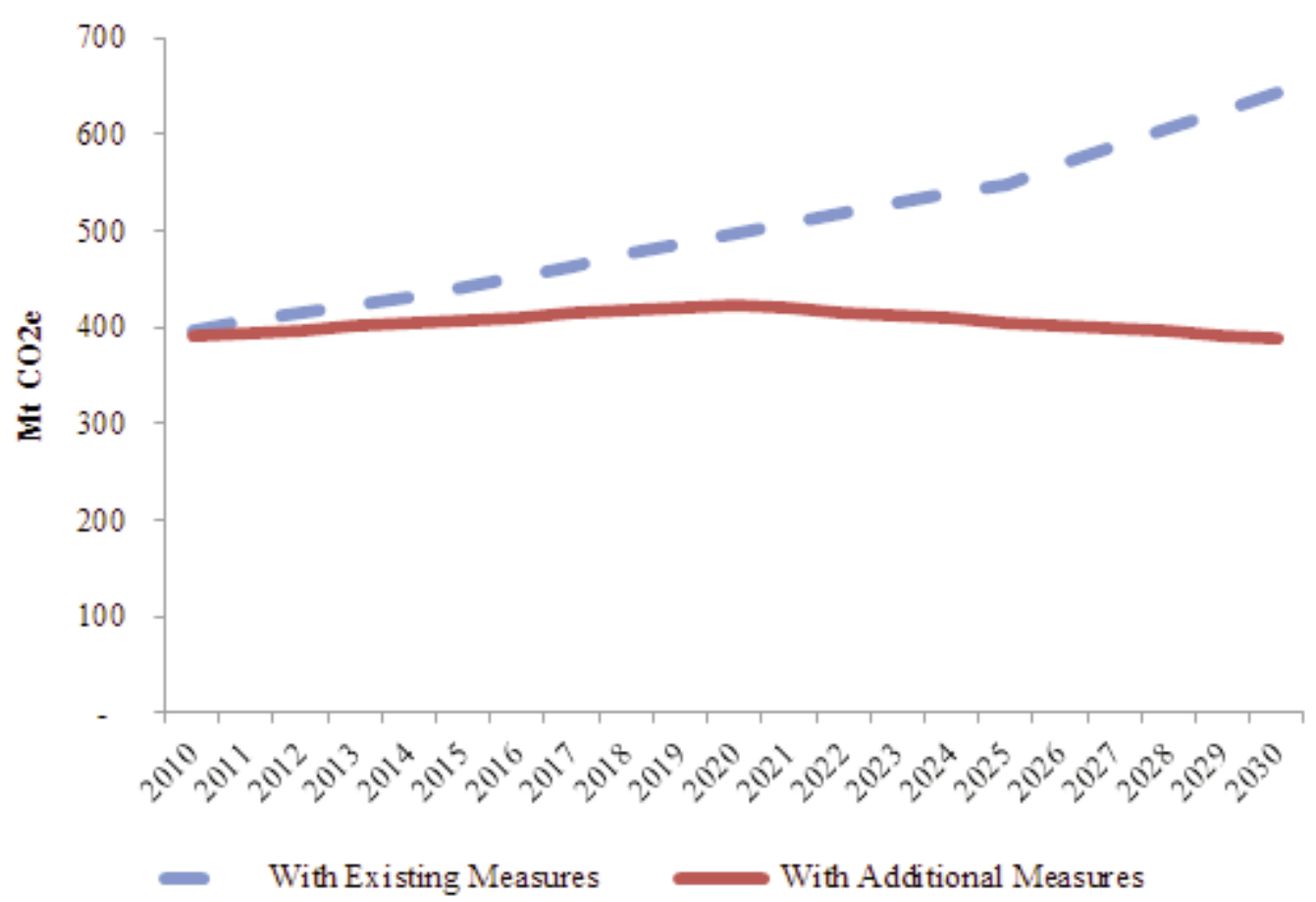

Figure 3: Two emissions projections assuming $100 \%$ potential and $75 \%$ of emissions covered by tax, 2016 to 2030, where CO2e = carbon dioxide equivalent; data from [60].

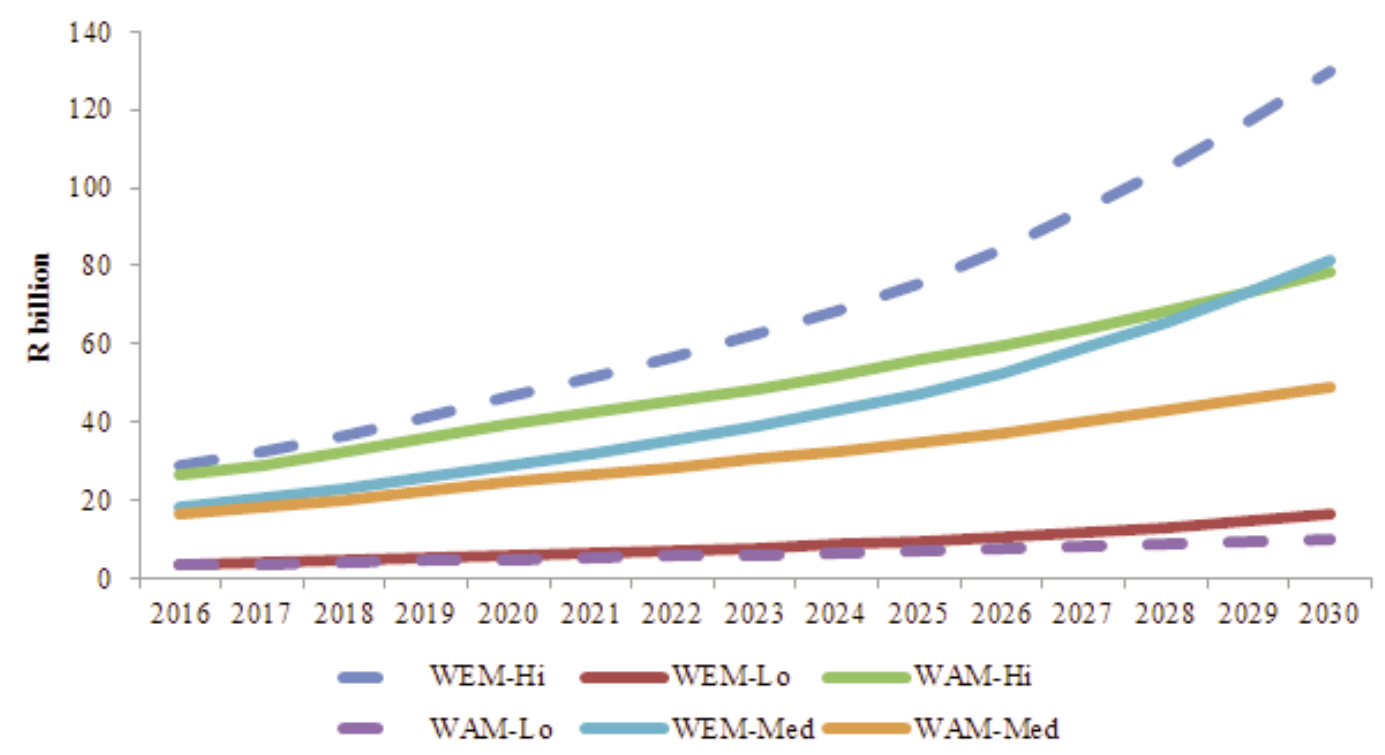

Figure 4: Carbon tax revenues under six scenarios; scenario names as defined in Table 1.

Two of the six possible options in Figure 4 and Table 1 are excluded from further analysis, removing those where the storylines are not internally consistent. The WEM-Hi would be a scenario in which emissions keep growing, which is not consistent with assuming a higher tax rate (though it is a separate question whether the tax rate considered was high enough in 'higher' to achieve WAM). Conversely, a significant decline of emissions at the lower tax rate is not internally consistent either, so WAM-Lo is also not considered further.

Having developed scenarios of carbon revenue from the initial year and over time, the study now turns to how revenue might be spent to reduce energy poverty.

\section{Expenditure to reduce (energy) poverty using different policy instruments}

This section examines possible programmes to reduce poverty, which could be financed by carbon revenue. Given that most of national emissions are from energy supply and use [52,61,62], this study focused on programmes that could help to ensure that poor households were at least as well off in terms of energy access under a carbon tax as without one, and that access was affordable [63]. The study considered options that have been rolled out at scale in South Africa already (notably further electrification), extending a programme (free basic electricity to other energy), and scaling-up from project to programme (sustainable housing) and an 
option from international experience not yet been seen widely in South Africa (rooftop solar home systems). An integrated strategy combining all four options (and their respective benefits) was also considered, but first this study turned to a more detailed description of each programme and the data and assumptions informing the spreadsheet modelling (see also the supplementary information). The quantified benefits are summarised in Table 2, after each programme was elaborated.

\subsection{Extend access by grid electrification}

Universal access to modern energy services has been a key goal of energy policy since 1998 [64]. The Department of Energy (DoE) in collaboration with Eskom and municipal distributors has implemented an Integrated National Electrification Programme (INEP) since the 1990s, with many aspects, including its funding, being evaluated in both official government documents and academic literature [65-67]. Funding further electrification from carbon revenues would free up National Treasury budget, electrification accounting for 3.2\% of the Medium-Term Expenditure Framework (MTEF) [53] and by far the largest portion of the DoE budget [68]. Expenditure on electrification is reported in Table 5.13 of the national budget review as a revised estimate of ZAR 5583 million for 2016/17, projecting increased expenditure of ZAR 6184 billion for 2017/18, ZAR 6432 billion for 2018/19 and ZAR 7792 billion by 2019/20 [53]. For this study, these projections are followed, and from 2020 to 2030 the assumption of an increase by the consumer price index plus $2 \%(\mathrm{CPI}+2)$ was adopted for this and the other programmes, to be consistent with the assumption of increased carbon revenue indicated by National Treasury [51].

Costs per connection were taken as equivalent to subsidies, which DoE gives as ZAR 18500 for urban and ZAR 19500 for rural connections for 2016/17 [69], so an average of ZAR 19000 was used here. The subsidy is increased annually at $\mathrm{CPI}+2$ (i.e. $8 \%$ ) as for all programmes, noting that National Treasury assumes electrification budgets to increase at $11.8 \%$ for the MTEF period [53]. The total revenue required is shown in Figure 6, with more detail in the supplementary information (the same applies for each of the further programmes in Sections 4.2 to 4.4 ).

Electrification might increase emissions, if the grid were not changing. The mix of electricity generation depended heavily on coal, resulting in 'combined margin emission factor' for South Africa of $0.957 \mathrm{tCO}_{2} / \mathrm{MWh}$ in 2009/2010 [70]. With increasing shares of renewable energy, which will benefit sustainability in social, economic and environmental dimensions [71-73], the official electricity plan projects a $34 \%$ decline in $\mathrm{CO}_{2}$ intensity from 2010 to 2030 [74]. Any increase of emissions is, therefore, likely to be reduced; though the reason for including the programme is its reduction in energy poverty.

\subsection{Extend free basic energy from electricity to liquefied petroleum gas}

Electrification provides physical access to electricity, whereas this next programme addresses affordability of energy. Programmes to make electricity affordable have been implemented, notably through free basic electricity [75], with an amount of typically 50-100 kWh provided free to poor households. While this is a significant portion of the electricity consumption of recently connected households [65], such an amount of electricity is enough only for lighting, entertainment and some appliances, but insufficient for many cooking needs and productive uses. More recently, consideration was given to providing free basic energy in other forms [76]. Providing liquefied petroleum gas (LPG) can extend energy services to cooking and productive uses, with using LPG safer than cooking on paraffin stoves and avoiding the health impacts of indoor use of coal or wood stoves. The $\mathrm{CO}_{2}$ emission factor for LPG is lower than that for sub-bituminous coal [58] - whether it is used indoors (also with health impacts) or for electricity, so that there may be some mitigation benefits of this poverty-alleviating measure. This study considered a programme that would subsidise a $5 \mathrm{~kg}$ cylinder per household per month to one million households (as a 'unit programme', for the purpose of further calculations). Maximum LPG prices are regulated, ranging from ZAR 9.54 to ZAR 120.13/kg [77], and an average value of ZAR 22.3/kg of LPG in 2016 is used, escalating at $\mathrm{CPI}+2$.

\subsection{Sustainable housing at scale - housing design, efficiency and solar water-heaters}

Providing affordable access to basic electricity and LPG are two ways of reducing energy poverty, but the question of houses themselves arises. The third programme considered in this study focused on sustainable housing. There are concerns about the quality of buildings, which can be improved at the same time as promoting energy efficiency and using renewable energy. The performance of simple energy-efficiency interventions are better understood, including ceilings (many houses are built without, insulation on ceilings, and wall insulation) and solar water-heaters [78] - referred to in this paper by the shorthand of 'sustainable housing'.

Literature points to the potential for projects to build sustainable housing [79]. Amongst others, the Kuyasa project in Khayelitsha Site C, Cape Town, included passive solar design [80,81]. The challenge is to scale-up from 2000 houses to a larger national programme, a National Sustainable Settlement Facility, which could channel invest- 
ments required and provide an institutional focus [82-84]. The Department of Human Settlements provides support for social housing; the incremental costs would be to fund the gap for better housing: 'This funding gap between standard and improved homes creates an additional financing requirement to support large-scale, climate-compatible housing delivery for the low-income sector in South Africa.' [82] The subsidy would be made available to households that cannot afford to meet the South African National Standard (SANS 10400-XA) on energy usage in buildings themselves, which requires the inclusion of energy efficiency interventions in all new buildings [85].

Informal housing is not typically energy-efficient. Although there was a significant housing programme in post-apartheid South Africa, with some 3.8 million subsidised housing units constructed, the housing backlog kept increasing because of migration. Dobson estimated an increased backlog on housing units from 1.5 million in 1996 to 2.1 million in 2011 [85], with a slightly lower number of 1.9 million estimated by a more recent report [86].

The build rate historically seems to have averaged 190000 units, taking 3.8 million subsidised units over 20 years [85], although some sources suggested 140000 as an average [86]. Given that needs might increase at 100000 houses per year, removing the backlog requires making the optimistic assumption. Figure 5 shows that a more optimistic build rate than historically seen is required, if the housing backlog is to be wiped out by 2030 .

At historical build rates, there would still be a backlog of 740000 houses in 2030. The optimistic build rate was assumed in this analysis - to explore how many sustainable houses the carbon tax revenue could fund. The focus was not on the operational requirements, but funding, and the incremental cost per house was a key factor.
The incremental cost was earlier estimated in a range of 'a further R15 000-R20 $000 \quad \ldots$ for improved energy efficiency measures (including thermal performance improvements and solar water heaters)' per household [82]; more recently a broader range of ZAR 10 000-20 000 was used [85]; ZAR 15000 per household was used for this analysis.

\subsection{Rooftop solar home systems for poor households}

The installation of rooftop solar systems reached large scale in other countries, for example, $3 \mathrm{GW}$ installations in Australia by 2013 [87], but is still limited in South Africa. The photovoltaic (PV) systems were installed in schools and clinics and concession areas remote from the grid as an alternative to grid-based electrification $[88,89]$. The size of systems for higher-income households may be 5.5 $\mathrm{kWp}$ or larger, but as the present analysis focused on poor households, $1.5 \mathrm{kWp}$ systems were considered. The average cost appears to range from ZAR 20000 to ZAR 22 000/kWp installed, including all the costs of connecting the system to the electricity grid [90]. Applying the average of ZAR 21 000, a $1.5 \mathrm{kWp}$ system costs ZAR 31500 . A 'unit programme' of 100000 households/year would then require total revenue of ZAR 3.15 billion currently, escalating at CPI+2.

\subsection{Estimated benefits of poverty reduction and an integrated programme.}

Table 2 summarises the main quantified benefits for each programme, and the 'unit programme' assumed for further calculations. For example, how many 'free basic energy' programmes could carbon revenue fund - half, or multiples, in the findings in the following section? It should be noted that, in Table 2 , the reference value for electrification is

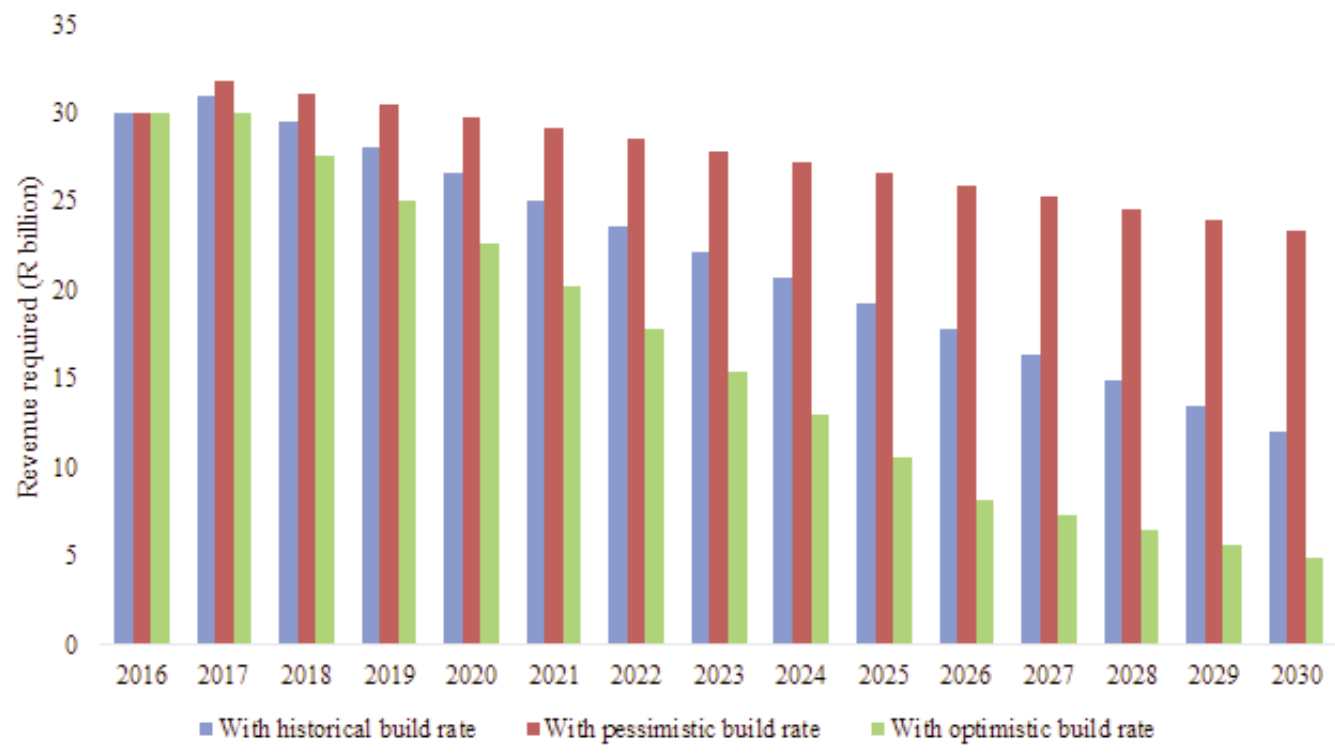

Figure 5: Revenue required to reduce housing backlog at different build rates. 
Table 2: Poverty reduction programmes, their main quantified benefits and co-benefits.

\begin{tabular}{|c|c|c|c|}
\hline Programme & Main quantified benefit & Unit programme for calculation & Co-benefits \\
\hline Electrification & $\begin{array}{l}\text { Connections of households } \\
\text { to electricity grid }\end{array}$ & $\begin{array}{c}260000 \text { connections } \\
\text { per year }\end{array}$ & Productive use of electricity \\
\hline $\begin{array}{l}\text { Free basic } \\
\text { energy (LPG) }\end{array}$ & $\begin{array}{l}\text { Households receiving } \\
5 \mathrm{~kg} \text { LPG per month }\end{array}$ & 1000000 households & $\begin{array}{l}\text { Fewer health and safety impacts by } \\
\text { replacing paraffin, wood or coal }\end{array}$ \\
\hline $\begin{array}{l}\text { Sustainable } \\
\text { housing }\end{array}$ & $\begin{array}{l}\text { Sustainable houses } \\
\text { improved by subsidy }\end{array}$ & 250000 houses & $\begin{array}{l}\text { Houses that are warmer in winter, cooler } \\
\text { in summer, have ceilings and hot water } \\
\text { - generally better houses; improved health } \\
\text { due to lower energy use required indoors }\end{array}$ \\
\hline $\begin{array}{l}\text { Rooftop solar } \\
\text { home system }\end{array}$ & $\begin{array}{l}\text { Households with fully } \\
\text { subsidised PV systems }\end{array}$ & 100000 households & $\begin{array}{l}\text { Household energy security / autonomy; } \\
\text { improved health due to lower energy } \\
\text { use required indoors }\end{array}$ \\
\hline
\end{tabular}

260000 households, as given by the Energy Minister for the 2015/16 financial year [91], but connection rates will depend on resources and institutional capacity. Similarly for sustainable housing, the build rates must be understood as a function of large new revenue sources. There may be higher build rates, but the historical build rates (140 000-190 000 per year) mentioned need to be considered in interpreting the results.

Table 2 shows the co-benefits, which are ancillary benefits to the main quantified outcome. It was noted that several of the programmes assist with health benefits, as poor households use less paraffin (common in the Western Cape Province), coal (Gauteng Province) or wood indoors, and using less of these fuels indoors reduces health impacts from air pollutants. Other benefits are specific in that the sustainable houses, apart from reducing energy bills, are simply better and more comfortable, as previously studied [92]. The benefits of electrification would depend on how electricity might be used productively, potentially generating income and employment, in addition to social benefits (e.g. lighting for education).

While the analysis thus far focused on individual programmes, no single technology or large pro- gramme was likely to reduce energy poverty on its own. An integrated strategy combining all four programmes is considered in the next section. The study turns to its main findings, regarding how much poverty can be reduced through carbon revenue.

\section{Findings: To what extent might carbon tax revenues reduce poverty?}

The expenditure required by each of the four programmes is shown in Figure 6. It shows that sustainable housing requires the largest expenditure initially, but reduces over time, with the optimistic build rate reducing the housing backlog, while the other three programmes require gradually increasing expenditure, driven by CPI +2 . Fuller details calculations are in the supplementary information file. The total scale of funding is the line at the top of all four programmes 'stacked' in Figure 6, ranging approximately between ZAR 30 and ZAR 40 billion/year, as can be seen in the supplementary information file.

\subsection{Quantified benefits if all revenue were spent on one programme}

Table 3 shows the specific quantified benefits, if all

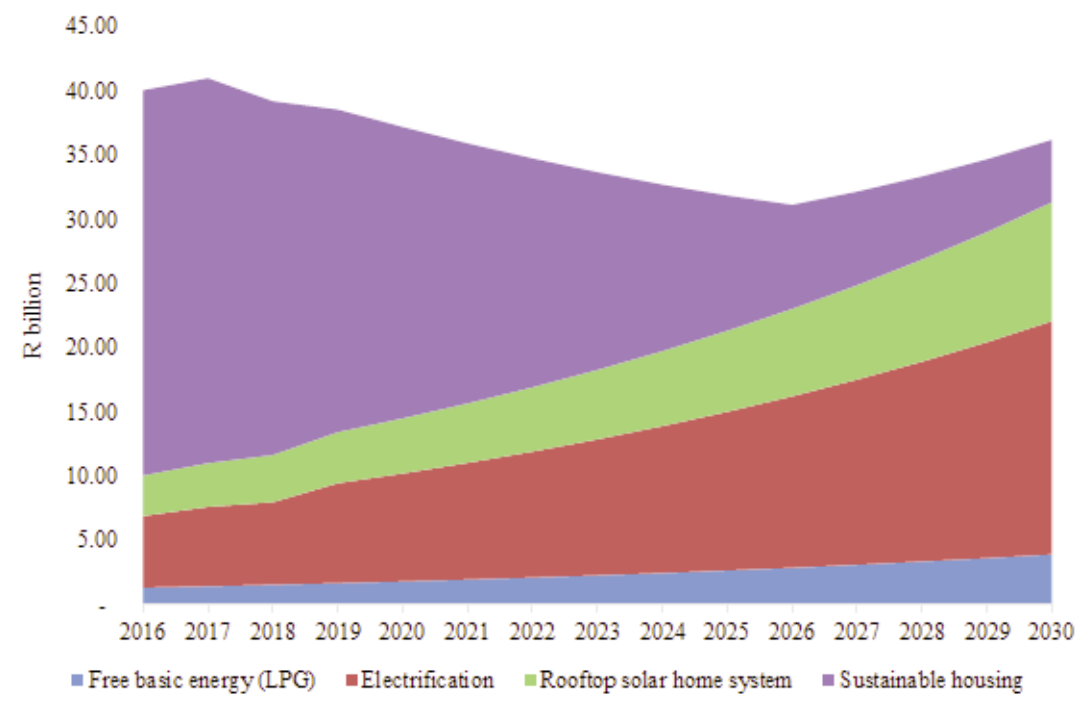

Figure 6: Expenditure required for four energy poverty reduction programmes. 
Table 3: Quantified benefits of four programmes, for four carbon revenues scenarios and selected years (Scenario names as defined in Table 1).

\begin{tabular}{|c|c|c|c|c|}
\hline & 2016 & 2020 & 2025 & 2030 \\
\hline Electrification & \multicolumn{4}{|c|}{ Connections of households to electricity grid } \\
\hline WEM-Hi & 1800000 & 1900000 & 2100000 & 2500000 \\
\hline WAM-Lo & 200000 & 200000 & 200000 & 200000 \\
\hline WEM-Med & 1100000 & 1200000 & 1300000 & 1600000 \\
\hline WAM-Med & 1000000 & 1000000 & 1000000 & 900000 \\
\hline Free basic energy & \multicolumn{4}{|c|}{ Households receiving $5 \mathrm{~kg} L P G$ per month } \\
\hline WEM-Hi & 21700000 & 25600000 & 28300000 & 33200000 \\
\hline WAM-Lo & 2500000 & 2700000 & 2600000 & 2500000 \\
\hline WEM-Med & 13500000 & 16000000 & 17700000 & 20700000 \\
\hline WAM-Med & 12300000 & 13600000 & 13100000 & 12500000 \\
\hline Sustainable housing & \multicolumn{4}{|c|}{ Houses built } \\
\hline WEM-Hi & 200000 & 500000 & 1800000 & 6700000 \\
\hline WAM-Lo & 30000 & 100000 & 200000 & 500000 \\
\hline WEM-Med & 200000 & 300000 & 1100000 & 4200000 \\
\hline WAM-Med & 100000 & 300000 & 800000 & 2500000 \\
\hline Rooftop solar & \multicolumn{4}{|c|}{ Households with fully subsidised photovoltaic systems } \\
\hline WEM-Hi & 900000 & 1100000 & 1200000 & 1400000 \\
\hline WAM-Lo & 100000 & 100000 & 100000 & 100000 \\
\hline WEM-Med & 600000 & 700000 & 700000 & 900000 \\
\hline WAM-Med & 500000 & 600000 & 600000 & 500000 \\
\hline
\end{tabular}

carbon revenue in the four scenarios (WEM-Hi, WAM-Lo, WEM-Med and WAM-Med) were spent on a single programme. The benefits were quantified in its physical units specific to each programme: connections of households to the grid, households receiving subsidised LPG, sustainable houses built and rooftop solar systems. Benefits on the scale of hundreds of thousands to several millions (in each unit) could be funded annually by carbon revenue. Values in Table 3 have been rounded to the nearest hundred thousand.

The largest quantified benefit is 33.2 million households receiving free basic energy in 2030 under the WEM-Hi scenario. This number is roughly double the total number of households in South Africa, 16.7 million in 2016 [93]. The results should be understood as the quantified benefits of energy poverty reduction that could be funded by carbon revenue, if no other constraints were present. Another way of considering the result is that a scenario with high emissions and tax rate would generate tax revenue in which twice as much free LPG could be funded in 2030 (pace institutional and other constraints). When assuming more mitigation and therefore fewer emissions taxed and a medium tax rate, still 12.5 million households' free LPG could be funded.

The WEM-Lo scenario can fund 200000 connections to the electricity grid per year. Given little mitigation and a tax rate of ZAR 6, connections stay constant over time in rounded numbers. The WAM$\mathrm{Hi}$ has the maximum number of connections, reaching 2.5 million in 2050. From Section 4.1, the study seeks to bring forward an understanding that this exceeds the historical capacity to rollout electrification by two orders of magnitude. This study makes no suggestion that this rate is feasible, given institutional and operational constraints, but the findings are the benefits that can be funded from carbon tax revenues.

The results in Table 3 further show that the incremental costs for between 30000 and 6.7 million improved houses could be funded per year, which is a wide range, depending on four carbon tax revenue scenarios. These are the costs of improvements, in addition to housing subsidies, as mentioned in Section 4.3. There is ample carbon revenue generated to fund building more efficient and sustainable houses for poor households.

Under different carbon revenue tax scenarios, an average of 600000 households could receive fully subsidised rooftop solar with the full range from 100000 to 1.4 million households. These are $1.5 \mathrm{kWp}$ systems for poor households, as described in Section 4.4. Not considered in this study, given its focus on poverty reduction, is a $50 \%$ subsidy, with the other half paid by middle-class households, which could be applied in other income groups differentially.

\subsection{Reducing energy poverty by combined programmes}

An integrated strategy combining a set of programmes is more likely to reduce energy poverty 
Table 4: Number of combined energy poverty programmes that could be funded in different carbon revenue scenarios (Scenario names as defined in Table 1).

\begin{tabular}{lcccc}
\hline & WEM-Hi & WAM-Lo & WEM-Med & WAM-Med \\
\hline 2016 & 0.7 & 0.2 & 0.5 & 0.4 \\
2017 & 0.8 & 0.2 & 0.5 & 0.4 \\
2018 & 0.9 & 0.2 & 0.6 & 0.5 \\
2019 & 1.1 & 0.2 & 0.7 & 0.6 \\
2020 & 1.3 & 0.3 & 0.8 & 0.7 \\
2021 & 1.4 & 0.3 & 0.9 & 0.7 \\
2022 & 1.6 & 0.3 & 1.0 & 0.8 \\
2023 & 1.9 & 0.4 & 1.2 & 0.9 \\
2024 & 2.1 & 0.4 & 1.3 & 1.0 \\
2025 & 2.4 & 0.4 & 1.5 & 1.1 \\
2026 & 2.7 & 0.5 & 1.7 & 1.2 \\
2027 & 3.1 & 0.5 & 1.9 & 1.3 \\
2028 & 3.5 & 0.6 & 2.2 & 1.4 \\
2029 & 3.9 & 0.6 & 2.5 & 1.5 \\
2030 & 4.4 & 0.7 & 2.7 & 1.7 \\
\hline
\end{tabular}

Note: Shaded cells indicate that there is insufficient revenue to fund all four programmes in that year and bold cells the years in which more than twice the carbon revenues are available for the combined programmes, while plain cells indicate that there is still more than sufficient funding to implement four energy poverty programmes outlined in this study.

than investing all revenues in one option. Table 4 presents the carbon revenues from four scenarios applied to the combination of all four programmes.

Considering the plain cells in Table 4, there is sufficient funding for the combined four energy poverty programmes in three of the four scenarios: by 2019 in WEM-Hi, three years later in WEM-Med (assuming a medium tax rate) and after a further two years (i.e. by 2024) in WAM-Med (more mitigation is assumed and hence fewer emissions taxed).

The differences in the results in Table 4 are driven primarily by the respective tax rate, with more integrated poverty reduction being funded at the high tax rate of ZAR 48, compared to the low rate of ZAR 6 as expressed Section 3.2. Comparing the two scenarios with medium tax rates, more poverty can be funded if only existing measures were taken (WEM-Med), whereas the WAM-Med scenario spends more on mitigation. There is, however, a clear trend over time, and more poverty reduction could be funded over time.

Over time, Table 4 shows that carbon revenues applied at the range of tax rates in draft legislation and to all emissions can fund an integrated strategy, combining four energy poverty reduction programmes. By 2030, even the lowest carbon revenue scenario (WAM-Lo) funds about $70 \%$ of the combined cost of electrification, free LPG, improved sustainable housing and subsidised rooftop solar. In the other three scenarios, depending on tax rate and emissions projections, Table 4 indicates that full-funding-equivalence is reached by 2019,2022 or 2024. It is reasonable, on this basis, to deduce that carbon revenue can fund combined energy poverty reduction in the near-to-medium term in South Africa.

\section{Limitations, possible extensions and future work}

Turning to limitations of this study, one is that the spatial scale here was national and limited to one country. Future analysis of carbon pricing and reducing poverty, particularly in other developing countries, might provide comparison, learning from what is similar as well as differences.

The study noted that no single programme is likely to eradicate energy poverty on its own. Further programmes could be added to the four considered here. The consideration of integrated or combined programmes should also, as noted, pay attention to the institutional and operational dimensions of rolling out poverty reduction programmes. Case studies drawing on experience of the expanded public works programmes, indigent policies and programmes in cities and rural areas, as well as other existing programmes, would be a useful complement to the present analysis.

Methodologically, the analysis is based on a simple spreadsheet model, which is provided as supplementary information. This has the advantage of transparency, and is useful for an initial proof of concept. However, the interactions between different energy poverty programmes and the energyeconomic analysis, could be explored in an energy system model [94] or linked energy-economic models [95]. The latter would be useful in providing fur- 
ther information on the job-creation potential and other socio-economic benefits, not only directly in the energy sector but also accounting for linkages to the rest of the economy.

The research question and analysis in this study might be considered to have internal contradictions. Some of the poverty programmes analysed here could be considered to increase emissions, which is at odds with the principles of a carbon tax. The options of electrification and free LPG entail GHG emissions. While this is considered in sections 4.1 and 4.2 respectively, the analysis could have limited the energy interventions to low-emissions option. However, such an approach limits poverty reduction options, in a manner that runs the risk of conveying that that 'the rich get richer and the poor get renewables' [96]. This study treated poverty and mitigation as independent factors; further work that might relate the two would be complementary.

This study did not analyse carbon taxes as Pigouvian taxes, which internalise the costs of negative externalities. The author considers the development of tax rates that are equal to the social cost of the externality to be beyond the scope of a single study that also develops the revenue scenarios, programmes and compares revenues and expenditures. A study on carbon taxes that reflect the full cost of externalities deserves a paper of its own. Here, the scope was limited and a simpler starting point to focus on answering its research question was adopted.

Treasury assumptions were followed, notably applying carbon tax to all emissions in the inventory[51], but reducing the tax rate as in draft legislation [50] as discussed in Section 3. Once company or facility-level carbon budgets are enforced, it might be of interest to analyse the revenues generated by taxing only those emissions above the allowable carbon budget. On first principles, applying the same rates to a smaller amount of emissions would yield less revenue. On the other hand, the effective tax rates are very low (ZAR 6-48, roughly USD 0.5-4, per ton $\mathrm{CO}_{2}-\mathrm{eq}$ ) and higher carbon prices would be necessary globally to achieve the temperature goals of the Paris Agreement [4]. Future work might consider higher tax rates, applied to emissions above an allowable threshold.

Future work might examine emission projections that result from assumed tax rates, treating them as dependent variables. System models as mentioned above might consider how dependent variables could be modelled, while paying attention to the use and misuse of models [97].

Another limitation is that the paper examines the scale of revenue and equivalent expenditure, and does not propose or examine the budgetary process required to allocate expenditure. It was noted at the outset that no proposal for ring-fencing of revenues is made; this provides another reason to treat mitigation and poverty as independent variables. Further work might examine budget-allocation processes and how these balance policy objectives and principles of good public finance management.

If such future work were undertaken, it might also move from the aggregate national scale to consider the implications at local (company) level. Future studies could examine carbon revenues that might be payable by Eskom, Sasol, members of the energy intensive users group, and other major emitters in South Africa, and whether there are means for them to spend directly on reducing energy poverty or if this might be done more efficiently via the fiscus. Such work might also disaggregate emissions by scope or definitions in Schedule 2 of the Carbon Tax Bill.

The analysis supports findings related to funding from carbon tax revenues only. Institutional capacity or operational constraints would have to be addressed in further work. It is with this in mind that the paper turns to its conclusions.

\section{Conclusions}

This study explored the question posed at the outset: How much can poverty be reduced through carbon tax revenue? Scenarios of carbon revenues, at different tax rates and emission projections were developed in a spreadsheet model. Four energy poverty reduction programmes were examined: electrification, free LPG, improved sustainable housing and subsidised rooftop solar (see the supplementary information).

The overall finding of this study was that energy poverty could be reduced by expenditure of carbon tax revenues. This finding was supported by results that applied the equivalence of carbon tax revenue to individual programmes and an integrated strategy.

If the equivalent of all carbon revenue in a scenario were applied to a single programme, then significant number of connections, subsidies, systems and improved houses could be funded. If companies were to pay a medium tax rate of ZAR 30 per ton, revenues would more than cover the national budget of electrification, from one 'unit programme' on the scale of INEP to even larger programme funding, with the ancillary benefits of productive use of electricity. Several million households could receive free energy in the form of $5 \mathrm{~kg}$ of LPG every month, more than the current number of households. Results should be understood as deriving from stated assumptions. Carbon revenue could fund better housing, by adding to the existing housing subsidy to fund passive solar design, energy-efficient insulation and solar water-heaters. Even the lowest carbon revenue scenario considered here would fund 30000 improved houses initially, and more than the build rates observed historically by 
2030. For householders, the benefits may be experienced as houses that are warmer in winter and cooler in summer, with ceilings and hot water. Subsidies for at least 100000 rooftop solar systems per year are equivalent to even the lowest carbon revenue scenario; six times the assumed 'unit programme' or 600000 households is the average result. One co-benefit of rooftop solar is greater autonomy. Other significant health and safety cobenefits are expected by reducing air pollution from burning of fuels indoors for sustainable housing and rooftop solar. Even LPG can displace paraffin and wood- or coal-stoves.

The analysis showed that three of the four carbon revenue scenarios provided the equivalent of funding for an integrated programme, combining all four programmes; the lowest revenue scenario funds about $70 \%$. In the three scenarios, the combined four energy poverty reduction programmes reached full equivalence by 2019, 2022 or 2025 respectively. Based on these findings, it is concluded that, in the near-to-medium term, carbon revenue could provide equivalent funds for an integrated programme combining four large-scale energy poverty reduction interventions in South Africa.

\section{Note}

1. Supplementary data associated with this article can be found at http://journals.assaf.org.za/jesa/rt/ suppFiles/2332/0.

\section{References}

[1] UNFCCC 1992. United Nations Framework Convention on Climate Change. United Nations, New York, http://unfccc.int/resource/docs/2015 /cop21/eng/10a01.pdf

[2] Geden, O. 2016. An actionable climate target. Nature Geoscience, 9(5), 340-342, 10.1038/ ngeo2699.

[3] Rogelj, J., Schaeffer, M., Meinshausen, M., Knutti, R., Alcamo, J., Riahi, K. and Hare, W. 2015. Zero emission targets as long-term global goals for climate protection. Environmental Research Letters, 10, 105007, doi:10.1088/1748-9326/10/10/ 105007.

[4] UNFCCC (United Nations Framework Convention on Climate Change). 2015. Paris Agreement. Annex to decision 1/CP.21, document FCCC/CP/ 2015/10/Add.1, 29 January 2016. United Nations, Paris, France, http://unfccc.int/ resource/docs/2015/ cop21/eng/10a01.pdf - page $=2$.

[5] United Nations 2014. Outcome document - Open Working Group on Sustainable Development Goals. United Nations, New York, http://sustainabledevelopment.un.org/focussdgs.html.

[6] National Treasury 2006. A framework for considering market-based instruments to support environmental fiscal reform in South Africa. Draft policy paper. National Treasury Tax Policy Chief Directorate, Pretoria, http://www.treasury.gov.za/ tax/default.htm.
[7] National Treasury 2003. Market-based instruments to support environmental fiscal reform in South Africa: A discussion document. National Treasury, Pretoria.

[8] Eunomia and UP (Eunomia research and consulting, and University of Pretoria). 2004.

Development of a framework for market-based instruments to support environmental fiscal reform in South Africa. A draft final report for National Treasury of South Africa. Not for citation. Treasury, Pretoria.

[9] NPC (National Planning Commission). 2011. National development plan: Vision for 2030. The Presidency, Republic of South Africa, Pretoria, http://www.gov.za/sites/www.gov.za/files/Executive Summary-NDP 2030 - Our future - make it work.pdf.

[10] National Treasury 2013. Carbon Tax Policy Paper: Reducing Greenhouse Gas Emissions and Facilitating the Transition to a Green Economy. Policy paper for public comment, May 2013. Republic of South Africa, Pretoria, http://www.info. gov.za/view/DownloadFileAction?id=189311

[11] Winkler, H., Boyd, A., Torres Gunfaus, M. and Raubenheimer, S. 2015. Reconsidering development by reflecting on climate change International Environmental Agreements, 15(4), 369-385, DOI 10.1007/s10784-015-9304-7.

[12] Grubb, M. 2014. Planetary economics: Energy, climate change and the three domains of sustainable development. with Jean-Charles Hourcade and Karsten Neuhoff. Routledge, London and New York.

[13] MCA4climate (Multi criteria analysis for climate change). 2011. A practical framework for planning pro-development climate policies. United Nations Environment Programme, Riso, http://www. mca4climate.info/_assets/files/MCA4climate_Summ ary.pdf.

[14] World Bank. 2010.World Development Report 2010: Development and climate change. The World Bank, Washington D.C.

[15] Dubash, N. 2009. Climate change and development: A bottom-up approach to mitigation for developing countries? in Climate finance: Regulatory and funding strategies for cimate change and global development (eds. Steward, R.B., Kingsbury, B. and Rudyk, B.) 172-178, New York University Press, New York.

[16] Bierbaum, R.M. and Zoellick, R.B. 2009. Development and climate change. Science, 326 (771), doi: 10.1126/science.1183876.

[17] Halsnæs, K. and Shukla, P. 2008. Sustainable development as a framework for developing country participation in international climate change policies. Mitigation and Adaptation Strategies for Global Change, 13, 105-130, doi: 10.1007/ s11027-006-9079-9.

[18] South Centre. 2007. Integrating development in climate change: A framework policy discussion paper on key elements for the development of the post-2012 global climate policy regime South Centre, Geneva. http://tinyurl.com/y7s6uyov.

[19] Shukla, P.R. 2006. Integrating sustainable develop- 
ment and climate policies: Case studies of energy sector in India in Sustainable development, energy and climate change: Methodological issues and case studies from Brazil, China, India, South Africa, Bangladesh and Senegal. ISBN 87-5503452-6 (eds. Halsnaes, K. and Garg, A.) 27-26, UNEP Ris $\varnothing$ Centre, Roskilde.

[20] Munasinghe, M. and Swart, R. 2005.Primer on climate change and sustainable development: Facts, policy analysis and applications. Cambridge University Press, Cambridge.

[21] IPCC. 2014. Climate Change 2014: Synthesis Report. Fifth Assessment Report of the Intergovernmental Panel on Climate Change. Geneva.

[22] Sathaye, J., Najam, A., Cocklin, C., Heller, T., Lecocq, F., Llanes-Regueiro, J., Pan, J., PetschelHeld, G., Rayner, S., Robinson, J., Schaeffer, R., Sokona, Y., Swart, R. and Winkler, H. 2007. Sustainable development and mitigation. Chapter 12 in Climate Change 2007: Mitigation, Contribution of Working Group III to the IPCC Fourth Assessment Report (eds. Metz, B., Davidson, O.D., Bosch, P., Dave, R. and Meyer, L.M.) Cambridge University Press.

[23] Banuri, T. and Weyant, J.P. 2001. Setting the stage: Climate change and sustainable development. in Climate Change 2001: Mitigation: Contribution of WG III to the Third Assessment Report of the IPCC 74-114, Cambridge University Press, Intergovernmental Panel on Climate Change.

[24] IPCC (Intergovernmental Panel on Climate Change). 1996. Climate change 1995 : economic and social dimensions of climate change. Second Assessment Report of the Intergovernmental Panel on Climate Change. Working Group III. Cambridge University Press, Cambridge [England] ; New York.

[25] UN 2015. Resolution adopted by the General Assembly on 25 September 2015: Transforming our world: the 2030 Agenda for Sustainable Development. A/RES/70/1 (Sustainable Development Goals - SDGs). United Nations, New York, http://www.un.org/ga/search/ view_doc.asp?symbol=A/RES/70/1\&Lang $=\mathrm{E}$.

[26] Winkler, H., Spalding-Fecher, R., Mwakasonda, S. and Davidson, O. 2002. Sustainable development policies and measures: Starting from development to tackle climate change in Building on the Kyoto Protocol: Options for protecting the climate (eds. Baumert, K., Blanchard, O., Llosa, S. and Perkaus, J.F.) 61-87, World Resources Institute, Washington DC.

[27] Winkler, H., Höhne, N. and Den Elzen, M. 2008 Methods for quantifying the benefits of sustainable development policies and measures (SD-PAMs). Climate Policy, 8(2), 119-134.

[28] Winkler, H., Howells, M. and Baumert, K. 2007. Sustainable development policies and measures: institutional issues and electrical efficiency in South Africa. Climate Policy, 7 (3), 212-229.

[29] Höhne, N. and Moltmann, S. 2007. Linking national climate and sustainable development policies with the post-2012 climate regime: Proposals in the energy sector for Brazil, China, India, South Africa and South Korea, Ecofys, Cologne.
[30] RSA. 2006. Dialogue working paper 18: Submission from South Africa: Sustainable Development Policies and Measures. 3 Department of Environmental Affairs \& Tourism, Pretoria.

[31] Baumert, K. and Winkler, H. 2005. SD-PAMs and international climate agreements. Chapter 2 in Growing in the greenhouse: Protecting the climate by putting development first (eds. Bradley, R. and Baumert, K.A.) 15-23, World Resources Institute, Washington, D.C.

[32] UNFCCC (United Nations Framework Convention on Climate Change). 2007. Bali Action Plan. Decision 1/CP.13. Bali, Indonesia.

[33] Sen, A. 1981.Poverty and famines : an essay on entitlement and deprivation Clarendon, Oxford.

[34] SSA (Statistics South Africa). 2014. The South African MPI: Creating a multidimensional poverty index using census data. SSA, Pretoria, http://beta2.statssa.gov.za/publications/Report-0310-08/Report-03-10-082014.pdf.

[35] Merven, B., Moyo, A., Stone, A., Dane, A. and Winkler, H. 2014. The socio-economic implications of mitigation actions in the power generation sector and carbon taxes in South Africa. Working paper for CDKN project on Linking sectoral and economy-wide models, Energy Research Centre, University of Cape Town, Cape Town. http://www.erc.uct.ac.za/sites/default/files/image_too 1/images/119/Papers-2014/14-Merven-etalSocioeconomic_implications.pdf.

[36] Cloete, B. and Tyler, E. 2012. Carbon tax design options: A discussion document. Prepared for WWF South Africa, WWF-SA, Cape Town.

[37] Vorster, S., Winkler, H. and Jooste, M. 2011. Mitigating climate change through carbon pricing An emerging policy debate in South Africa. Climate and Development, 3(3), 242-258.

[38] Winkler, H., Marquard, A. and Jooste, M. 2010. Putting a price on carbon: Economic instruments to mitigate climate change in South Africa and other developing countries, Proceedings of the conference held on 23-24 March 2010 in Cape Town. ISBN 978-0-7992-2357-6, Energy Research Centre, University of Cape Town.

[39] Devarajan, S., Go, D.S., Robinson, S. and Thierfelder, K. 2009. Tax policy to reduce carbon emissions in South Africa. in Economy-wide Analysis and Economic Policy. Symposium, 28-29 May 2009, National Treasury, Pretoria.

[40] Winkler, H. and Marquard, A. 2011. Analysis of the economic implications of a carbon tax. Journal of Energy in Southern Africa, 22(1), 55-68.

[41] Alton, T., Arndt, C., Davies, R., Hartley, F., Makrelov, K., Thurlow, J. and Ubogu, D. 2014. The economic implications of introducing carbon taxes in South Africa. Working Paper No. 2012/ 046, May 2012. Applied Energy, 116, 344-354.

[42] Atkins, P. and Prasad, G. 2013 Leveraging carbon revenue for poverty alleviation. in Conference on Strategies to Overcome Poverty and Inequality: Towards Carnegie III. 3-7 Sept. 2012, University of Cape Town.

[43] Ürge-Vorsatz, D. and Herrero, S.T. 2012. Building synergies between climate change mitigation and 
energy poverty alleviation. Energy Policy 49, 8390.

[44] IEA, UNDP and UNIDO (International Energy Agency, United Nations Development Programme and United Nations Industrial Development Organisation). 2010. Energy poverty: How to make modern energy access universal? Special early excerpt of the World Energy Outlook 2010 for the UN General Assembly on the Millennium Development Goals. Paris: Organisation for Economic Co-operation and Development/ International Energy Agency. http://www.worldenergyoutlook.org/docs/weo2010/weo2010_poverty.pdf

[45] Bazilian, M., Sagar, A.D., Detchon, R. and Yumkella, K. 2010. More heat and light. Viewpoint. Energy Policy, 38(10), 5409-5412.

[46] CURES (Citizens United for Renewable Energy and Sustainability). 2009. Exploring energy poverty in South Africa. Midrand.

[47] Sagar, A.D. 2005. Alleviating energy poverty for the world 's poor. Energy Policy, 33, $1367-1372$.

[48] WEC (World Energy Council). 1999. The challenge of rural energy poverty in developing countries. World Energy Council and Food and Agriculture Organisation, London.

[49] Boardman, B. 2012. Fuel poverty synthesis: Lessons learnt, actions needed. Energy Policy 49, 143-148.

[50] National Treasury 2015. Draft carbon tax bill. Minister of Finance, Pretoria, http://www.treasury. gov.za/public comments/CarbonTaxBill2015/ Carbon Tax Bill final for release for comment.pdf.

[51] National Treasury 2015. Market Readiness Proposal, to World Bank Partnership for Market Readiness Republic of South Africa, Pretoria, https://www.thepmr.org/system/files/documents/Sou th Africa Final MRP_16 Feb 2015.pdf

[52] DEA (Department of Environmental Affairs). 2014. Greenhouse gas inventory for South Africa, 20002010. DEA, Pretoria, https://www.environment. gov.za/sites/default/files/reports/2000_2010_nationalghginventoryreport.pdf.

[53] National Treasury 2017. Budget review. Pretoria, http://www.treasury.gov.za/documents/national budget/2017/review/FullBR.pdf.

[54] Alcamo, J. and Henrichs, T. 2008. Towards guidelines for environmental scenario analysis in Environmental futures: the practice of environmental scenario analysis (ed. Alcamo, J.) 13-35, Elsevier, Amsterdam.

[55] Brummel, A. and MacGillivray, G. undated. Introduction to scenarios, Scenarios to Strategy Inc. http://www.scenarios2strategy.com/pdf/Introduction to Scenarios and Scenario Planning.pdf.

[56] DEA (Department of Environment Affairs). 2014. South Africa's greenhouse gas mitigation potential analysis. Technical summary. DEA Pretoria, https:/www.environment.gov.za/sites/default/files/do cs/technicalsummary.pdf

[57] WRI and WBCSD 2007. The Greenhouse Gas Protocol: A corporate accounting and reporting standard. Revised edition. World Business Council for Sustainable Development \& World Resources Institute, Washington, http://www.ghgprotocol.org/.
[58] IPCC (Intergovernmental Panel on Climate Change). 2006. IPCC guidelines for national greenhouse gas inventories. Prepared by the National Greenhouse Gas Inventories Programme. Eggleston H.S., Buendia L., Miwa K., Ngara T. and Tanabe K. (eds). Institute for Global Environmental Strategies, Kanagawa, Japan, http://www.ipccnggip.iges.or.jp/public/2006gl/index.htm.

[59] Trading Economics. 2017. South Africa inflation rate forecast 2016-2020. online resource accessed http://www.tradingeconomics.com/southafrica/inflation-cpi/forecast.

[60] Joubert, A., Palmer, I., Forster, D., Mullins, D. and Curren, J. 2013. South Africa's greenhouse gas mitigation potential analysis, Department of Environment Affairs, Pretoria.

[61] DEA (Department of Environmental Affairs). 2016. South Africa's 2nd biennial update report DEA, Pretoria, https://www.environment.gov.za/sites/ default/files/reports/2ndBUR2000_2012_draftforpubliccomments.pdf.

[62] Winkler, H., Hughes, A., Marquard, A., Haw, M. and Merven, B. 2011. South Africa's greenhouse gas emissions under Business-as-Usual: The technical basis of 'Growth without Constraints' in the Long-Term Mitigation Scenarios. Energy Policy 39(10), 5818-5828.

[63] Winkler, H., Simões, A.F., La Rovere, E.L., Alam, M., Rahman, A. and Mwakasonda, S. 2011. Access and affordability of electricity in developing countries, doi:10.1016/j.worlddev.2010.02.021. World Development 39(6), 1037-1050.

[64] DME (Department of Minerals and Energy). 1998. White Paper on Energy Policy for South Africa. DME, Pretoria, http://www.dme.gov.za/pdfs/energy/planning/wp_energy_policy_1998.pdf

[65] Borchers, M., Qase, N., Gaunt, T., Mavhungu, J., Winkler, H., Afrane-Okese, Y. and Thom, C. 2001. National Electrification Programme evaluation: Summary report. Evaluation commissioned by the Department of Minerals \& Energy and the Development Bank of Southern Africa, Energy \& Development Research Centre, University of Cape Town, Cape Town.

[66] NECC (National Electrification Coordinating Committee). 2000. Electrification funding: Report from Fund \& Levy Task Team of NECC.

[67] Eberhard, R. 1999. Economic costs and benefits of electrification: A brief review of South African experience with a view to determining the implications for the electrification planning model, Cape Associates, Cape Town.

[68] DoE (Department of Energy). 2016. Budget review and recommendations report to the Portfolio Committee on Energy. Cape Town.

[69] DoE (Department of Energy). 2016. Suite of supply policy guidelines for the Integrated National Electrification Programme (INEP) 2016/17. DoE, Pretoria, http://www.energy.gov.za/files/policies/electrification/Suite-of-Supply-Policy-Guidelines-for-theIntegrated-National-2016-17.pdf.

[70] Spalding-Fecher, R. 2011. What is the carbon emission factor for the South African electricity grid? Journal of Energy in Southern Africa, 22(4), 8-12. 
[71] Sparks, D., Madhlopa, A., Samantha Keen, Moorlach, M., Dane, A., Krog, P. and Dlamini, T. 2014. Renewable energy choices and their water requirements in South Africa. Journal of Energy in Southern Africa, 25(4), 80-92.

[72] Votteler, R.G. and Brent, A.C. 2016. A literature review on the potential of renewable electricity sources for mining operations in South Africa. Journal of Energy in Southern Africa, 26(2), 1-21.

[73] Wlokas, H., Boyd, A. and Andolfi, M. 2012. Challenges for local community development in private sector-led renewable energy projects in South Africa: an evolving approach. Journal of Energy in Southern Africa, 23(4), 46-51.

[74] DoE (Department of Energy). 2011. Integrated resource plan for electricity, 2010-2030. Government Gazette No. 342636 May 2011. Pretoria.

[75] DME (Department of Minerals and Energy). 2003. Electricity basic services support tariff (free basic electricity) policy for the Republic of South Africa. Government Gazette Vol. 457, No. 25088. Pretoria, http://www.energy.gov.za/files/policies/Free Basic Electricity Policy 2003.pdf.

[76] DoE (Department of Energy,). 2013. Free Basic Alternative Energy/Free Basic Electricity. Pretoria.

[77] DoE (Department of Energy). 2016. Schedule: Maximum retail price of liquefied petroleum gas. Government Gazette No 39965. DoE, Pretoria, http://www.gov.za/sites/www.gov.za/files/39965_rg1 0594_gon497.pdf.

[78] Holm, D. 2000. Performance assessment of baseline energy-efficiency interventions and improved designs in Environmentally sound energy efficient low-cost housing for healthier, brighter and wealthier households, municipalities and nation. Final report (ed. Irurah, D.K.) A-1-1 to A-2-27, Environmentally Sound Low-cost Housing Task Team and USAID, Pretoria.

[79] Spalding-Fecher, R., Mqadi, L. and Oganne, G. 2003. Carbon financing for energy efficient lowcost housing. Journal of Energy in Southern Africa, 14(4), 128-134.

[80] SSN (SouthSouthNorth). 2004. Project design document for the Kuyasa project. Submitted to the Executive Board of the Clean Development Mechanism. SouthSouthNorth Project, Cape Town, https://cdm.unfccc.int/filestorage/F/S/_FS_2929896 57/Kuyasa PDD Final-2005.pdf?t=eHR8b3RlaHlyf DDt7T1TU7rjTHYxWNoW3KT3.

[81] AGAMA. 2003. City of Cape Town low-cost urban housing upgrade: Kuyasa, Khayelitsha. Thermal modelling, final report, Cape Town.

[82] SSN (SouthSouthNorth). 2011. Sustainable settlements facility. Online resource. SSN, Cape Town, http://southsouthnorth.org/sustainable-settlementsfacility-ssf/.

[83] DBSA. 2011. Meeting the financing challenge in low income housing for a low carbon and climate resilient future: Sustainable Settlements Facility. Briefing paper, Development Bank of Southern Africa, Johannesburg. http://www.dbsa.org/EN/ About-Us/Publications/Documents/Briefing Note COP17 Side Event 5 Dec-10-13.pdf.
[84] G:enesis (G:enesis Analytics ). 2008. The National Sustainable Housing Facility business and investment plan. Genesis Analytics Cape Town.

[85] Dobson, B. 2015. Energy \& thermal efficiency in government subsidised housing in South Africa. MAPS Research Paper - implementation case study, Mitigation Action Plans and Scenarios (MAPS), Cape Town. http://mapsprogramme.org/ wp-content/uploads/Case-Study_Energy-and-thermal-efficiency-in-low-income-housing.pdf.

[86] Africa Check. 2017. The housing situation in South Africa. Factsheet, online resource. online resource accessed 20 July 2017, https://africacheck.org/factsheets/factsheet-the-housing-situation-in-southafrica/.

[87] Parkinson, G. 2013. Rooftop solar PV reaches 3GW in Australia. in People power: Vol. 4.

[88] Mapako, M., Ranninger, H. and Matinga, M. 2004. Solar electrification by the concession approach in rural Limpopo province, Energy Research Centre, Cape Town.

[89] Wentzel, M. and Pickering, M. 2004. The potential impact of an electricity basic services tariff on nongrid electricity. Journal of Energy in Southern Africa, 15(1), 4-9.

[90] Borchers, M. 2017. Costs of rooftop solar systems in March 2017.

[91] Joemat-Pettersson, T. 2016. Energy Department budget speech vote 2016/17, by Energy Minister, Cape Town. http://www.gov.za/speeches/ministertina-joemat-pettersson-energy-dept-budget-speechvote-201617-11-may-2016-0000.

[92] Cousins, T. and Mahote, F. 2003. Assessment of the impact of energy efficiency interventions in a low-income housing settlement, Kuyasa, Khayelitsha. Social Research for Kuyasa Pilot CDM Project Activity, SouthSouthNorth, Cape Town.

[93] SSA (Statistics South Africa). 2016. General household survey. Statistical release P0318. SSA, Pretoria, http://www.statssa.gov.za/publications/ P0318/P03182016.pdf.

[94] ERC (Energy Research Centre, Systems Analysis \& Planning Group). 2013. Assumptions and methodologies in the South African TIMES (SATIM) energy model. Version 2.1, 2013/04/08. University of Cape Town.

[95] Merven, B., Arndt, C. and Winkler, H. 2017. The development of a linked modelling framework for analysing socio-economic impacts of energy and climate policies in South Africa. UNU WIDER working paper 2017/40, United Nations University World Institute for Development Economics Research (UNU-WIDER), Cape Town and Washington. https://www.wider.unu.edu/sites/ default/files/wp2017-40.pdf.

[96] Annecke, W. 2002. The rich get richer and the poor get renewables: the WSSD, energy and women, a malevolent perspective. Agenda, 52, 8 16.

[97] Pindyck, R.S. 2017. The use and misuse of models for climate policy. Review of Environmental Economics and Policy, 11(1), 100-114 DOI: doi.org/10.1093/reep/rew012. 